\title{
A Study of Rural Entrepreneurship and their Problems in Marathwada
}

\section{OPEN ACCESS}

Manuscript ID:

COM-2021-09044189

Volume: 9

Issue: 4

Month: October

Year: 2021

E-ISSN: 2582-6190

Received: 15.07.2021

Accepted: 09.09.2021

Published: 01.10.2021

Citation:

Kale, Dasharath. "A Study of Rural Entrepreneurship and Their Problems in Marathwada." ComFin Research, vol. 9, no. 4, 2021, pp. 7-10.

DOI:

https://doi.org/10.34293/ commerce.v9i4.4189

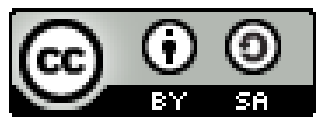

This work is licensed under a Creative Commons Attribution-ShareAlike 4.0 International License

\section{Dasharath Kale}

Assistant Professor, Department of Commerce

Vinayak Vidnyan Mahavidyalaya, Amravati, Maharashtra, India

(D) https://orcid.org/0000-0002-6296-2972

\begin{abstract}
This study was focus on the problems of rural entrepreneurs for increasing their business in Marathwada. The researcher has collected online data through Google from 150 respondents from Marathwada for the study during 2020-21. There are many reasons for decreasing entrepreneurship, but researchers think the main reason is that the youth should be aware of business education. The competition to do something new and better promotes entrepreneurship and there are many other reasons why Entrepreneurship is promoted. Rural entrepreneurs face many problems such as lack of skilled and managerial workforce, lack of infrastructural facilities for agri-business, marketing problems, lack of awareness regarding a career in agro-entrepreneurship, etc.

Keyword: Entrepreneurship, Rural entrepreneurship, Problems, Stores, Confidence, Awareness
\end{abstract}

\section{Introduction}

An entrepreneur is effective to control of commercial undertaking, one who undertakes a business or an enterprise. Entrepreneurial development nowadays has become very significant, given its being a key to economic development. The objectives of industrial development, regional increase, and employment age group depend upon entrepreneurial development.

\section{Concept of Entrepreneurship}

Entrepreneurs serve up as the catalyst in the economy's engine, triggering and stimulating all economic activity. Entrepreneurship is the act of location out on your own and starting a business in its place of working for someone in his business. It is a world of immense creativity and innovation inhabited by entrepreneurs, the individuals who innovate, take a risk and create value in the form of new products and services. These industries will employ the local people, they will be able to walk on the path of development, and this industry will make their daily life easier. They are mainly related to agriculture today, as agriculture is the main source of income in rural areas. Most importantly, the industry should not be run by youth in rural areas. All you need for this training is the idea of industry and the passion for maintaining social consciousness by making the industry successful.

\section{Significant of the Study}

Rural entrepreneurs can thrive through better agriculture and state-of-theart food processing industries to meet the hunger of the growing population. Today, however, the Indian economy is based on agriculture. 
The government has acknowledged that the development of the country still depends on the development of 60 percent of the people living in rural areas and efforts are being made for this. There is no doubt that results depend on implementation. The industries that have grown in India in the last five decades have grown in cities. As a result, people from rural areas flocked to cities in large numbers for employment. Poverty in urban areas increased and poverty persisted in rural areas with the question of development.

\section{Objectives}

- To know the significance of rural entrepreneurs in Marathwada.

- To find out the problems of rural Entrepreneurs in Marathwada.

\section{Research Methodology}

In the Marathwada region 8 districts that Beed, Aurangabad, Jalna, Parbhani, Hingoli, Osmanabad, Nanded, and later. The study is based on primary as well as secondary sources. The researcher has used both types of data. The researcher has collected online data through Google from 150 respondents from Marathwada.

\section{Scope of the Study}

The present study is related to the problems of rural entrepreneurs in Marathwada. The present study was scope and limitations on our part while undertaking the research study. This study is limited to the geographical area of Marathwada only.

\section{Problems of Rural Entrepreneurship}

- Not only in rural areas but also urban youth are not aware of this opportunity.

- No infrastructure, Electricity, water and technology are in short supply.

- The most important thing is that the lack of willpower. Young people don't even think that we can start an industry in rural areas.

- The most problems of training.

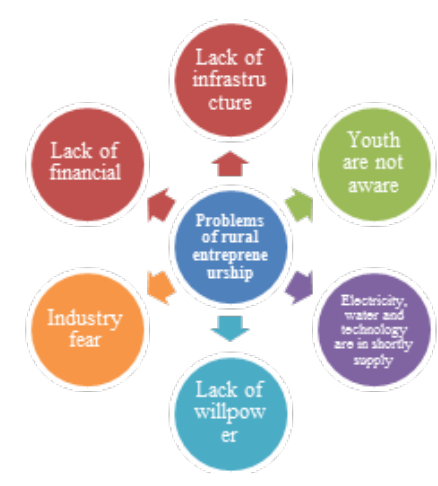

\section{Analysis and Presentation of Data}

This study deals with the analysis data and its presentations. The data were analyzed with the help of various tools and techniques such as tables, charts and various graphs etc. Various farmers and retailers, wholesalers and dealers were selected for the study.

Table 1: Education-wise Respondents

\begin{tabular}{|c|c|c|}
\hline Education & No of Respondents & (\%) \\
\hline HSC & 61 & 40.66 \\
\hline Graduate & 40 & 26.66 \\
\hline Post graduate & 09 & 06.00 \\
\hline Illiterate & 40 & 26.66 \\
\hline Total & $\mathbf{1 5 0}$ & $\mathbf{1 0 0}$ \\
\hline
\end{tabular}

Source: Online Survey 2021

\section{Graph}

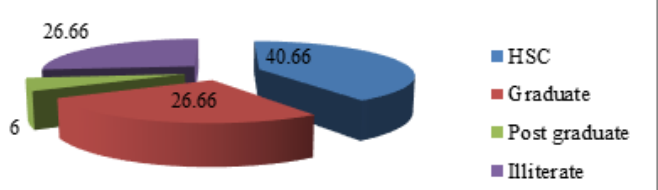

Source: Table No.1

Education for all is considered an important factor. Educational qualification of the respondent's response their differential education qualifications are HSC, Graduation, Post Graduation and Illiterate. Above the table shows that a maximum of $40.66 \%$ of respondents come under the Secondary or Higher Secondary; Graduate 26.26\%; Post-Graduate 06\% and Illiterate $26.26 \%$. It means that level of education was very high in Secondary or higher secondary and Graduate respondents. 
Table 2: Distribution of Problems of Rural Entrepreneurs

\begin{tabular}{|c|c|c|}
\hline Particulars & No of Respondents & $(\mathbf{\%})$ \\
\hline Yes & 95 & 63.33 \\
\hline No & 45 & 30.00 \\
\hline Don't know & 07 & 04.66 \\
\hline Neutral & 03 & 02.00 \\
\hline Total & $\mathbf{1 5 0}$ & $\mathbf{1 0 0}$ \\
\hline
\end{tabular}

Source: Online Survey 2021

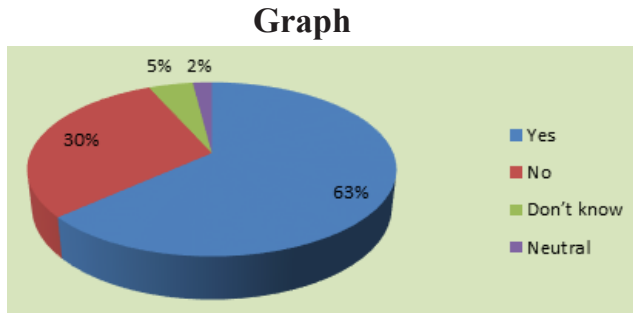

Source: Table No. 2

Table and graph no. 1.2 indicate that distribution as per problems in rural marketing in Marathwada. $63 . \%$ respondents were, they have difficulties or problems in rural marketing; 30\% respondents were, they have no difficulties or problems in rural marketing; $0.5 \%$ respondents were, they didn't know regarding difficulties in rural marketing and remaining $0.2 \%$ of respondents were, they have neutral about difficulties in rural marketing. It means that, $63 . \%$ respondents were, they have difficulties or problems in rural marketing.

Table 3: Distribution of Types of Problems

\begin{tabular}{|l|c|c|}
\hline \multicolumn{1}{|c|}{ Types of problems } & $\begin{array}{c}\text { No of } \\
\text { Respondents }\end{array}$ & (\%) \\
\hline Lack of infrastructure & 22 & 14.66 \\
\hline Youth are not aware & 27 & 18.00 \\
\hline $\begin{array}{l}\text { Electricity, water and } \\
\text { technology are in } \\
\text { shortly supply }\end{array}$ & 25 & 16.66 \\
\hline Lack of willpower & 40 & 26.66 \\
\hline Industry fear & 12 & 08.00 \\
\hline $\begin{array}{l}\text { Lack of information } \\
\text { about finance }\end{array}$ & $\mathbf{1 5 0}$ & 16.00 \\
\hline \multicolumn{1}{|c|}{ Total } & $\mathbf{1 0 0}$ \\
\hline
\end{tabular}

Source: Online Survey 2021

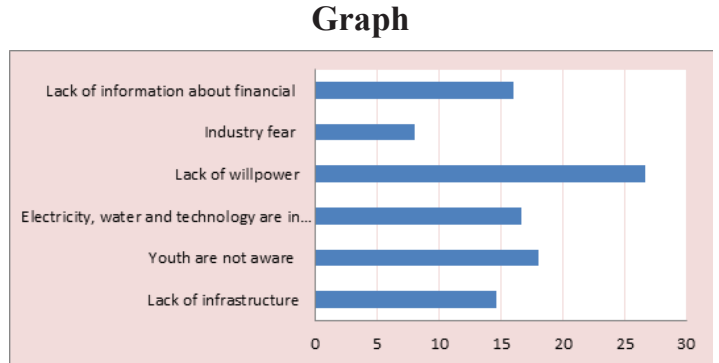

Source: Table No.1.3

Table and graph no. 1.3 indicate that distribution as per of types of problems. Above the table shows that a maximum of $22.67 \%$ of respondents was replied that they have difficulties in Lack of infrastructure facility regarding rural marketing in Marathwada; $22.23 \%$ of respondents were replied that Youth is not aware; $15.00 \%$ of respondents were replied that they have difficulties in Electricity, water and technology are in short supply; $18.67 \%$ respondents were replied that they not willpower about it; $10.33 \%$ respondents were replied that they have Industry fear; $11.00 \%$ respondents were replied that they have not sufficient information about finance. It means that a maximum of $22.67 \%$ of respondents was replied that they have difficulties in the Lack of infrastructure facility regarding rural marketing in Marathwada.

\section{Policy Challenges}

Major issues of difficulties in Lack of infrastructure facility regarding rural marketing in Marathwada, issues of that Youth are not aware; Issues of devolution of native and obsolete technology, Electricity, water and technology are in short supply, they will not power, Industry fear and they do not have sufficient information about finance.

\section{Conclusion}

Although Maharashtra has a reputation as a leading state in the country, its development process is also heterogeneous. Not only in rural areas but also urban youth are not aware of this opportunity. They have a problem, such as an infrastructure, electricity, water and technology are in short supply, lack of willpower and not training train properly. There should be an efficient regulated market and the government should also cooperate in this context. 
This study also concluded that $22.23 \%$ of youth are not aware; $15.00 \%$ have difficulties in Electricity, water and technologies are in short supply; $18.67 \%$ do not have willpower; $10.33 \%$ have Industry fear $11.00 \%$ have not sufficient information about finance.

\section{Suggestions}

Maximum Entrepreneur said that they have a face to face problems related to marketing. The lack of proper marketing facilities, exploitation by the arbitrators, and lack of information about market prices were some other obstacles. There should be awareness to Youth. In this context, state agencies and private agencies should be solution about it. Government should provide a separate financial fund for rural entrepreneurs and banks to provide easy finance. Assistance and encouragement should be provided to rural entrepreneurs for setting up marketing co-operatives in rural areas.

\section{References}

Bhuvaneswari, H., and S. Raju. "A Study on Rural Entrepreneurship with Sivaganga District." Global Research Analysis, vol. 3, no. 3, 2014, pp. 5-7.

Devi Prasad Kotni, V.V. "Prospects and Problems of Indian Rural Markets." Zenith International Journal of Business Economics \& Management Research, vol. 3, no. 3, 2012, pp. 200-213.

Goyal, Adheer. "Major Challenges and Problems of Rural Entrepreneurship in India." India's Emerging Economy : Challenges \& Opportunities in Rural India, 2018.

Ilahi, Saud. "Rural Entrepreneurship: The Current Scenario in India." International Journal of Science and Research, vol. 8, no. 11, 2018, pp. 1428-1432.

Joshi, J.V. "Rural Entrepreneurship: Strengths \& Problems - A Study with Reference to Nanded District." Chronicle of the Neville
Wadia Institute of Management Studies and Research, 2012, pp. 135-141.

Jayadatta, S. "Major Challenges and Problems of Rural Entrepreneurship in India." Journal of Business and Management, vol. 19, no. 9, 2017, pp. 35-44.

Kashide, Suresh. An Analytical Study of Soybean Production and Marketing in Hingoli District. Marathwada University, 2019.

Kumar, Pawan, and Neha Dangi. "Rural Marketing in India: Challenges and Opportunities." International Journal of Management and Social Sciences Research, vol. 2, no. 8, 2013.

Lokhande, Muridhar Ananada. "A Study of Demographic Dimensions of Entrepreneurship in India." International Journal of Social and Economic Research, vol. 6, no. 2, 2016, pp. 67-81.

Lokhande, Murlidhar A. "A Study of SocioEconomic Background of Entrepreneurs from Semi-urban Centers in Maharashtra." Professionals Center for Business Research, vol. 2, 2015.

Malick, T.V., and J. Jothi Krishnan. "Rural Marketing Strategies, Issues and Challenges." International Journal of Engineering and Management Research, vol. 4, no. 2, 2014, pp. 116-122.

Patil, Rachana, and Vineel Bhurke. "Impact of Rural Entrepreneurship on Migration - A Case Study of Dahanu (Maharashtra)." Indian Journal of Agricultural Research, 2019, pp. 500-503.

Sivanesan, R. "Problems of Rural Market in India - An Overview." International Journal of Research in Business Studies and Management, vol. 1, no. 2, 2014, pp. 1-7.

Sugaraj, Jadhawrao Madhavi, and P.S. Salve. "A Study of Women Entrepreneurship and their Problems in the Development in Western Maharashtra." Journal of Economics and Finance (IOSR-JEF), vol. 3, no. 2, 2014.

\section{Author Details}

Dr. Dasharath Kale, Assistant Professor, Department of Commerce, Vinayak Vidnyan Mahavidyalaya, Amravati, Maharashtra, India, Email ID: dkkale143@gmail.com 